\title{
Bioeconomy and Its Set of Innovations for Sustainability
}

Joachim von Braun

Center for Development Research, Bonn University,
Bonn, Germany

\section{The Emergence of the Knowledge-Based Bioeconomy}

I nitially, the bioeconomy was politically encouraged in anticipation of rapidly dwindling oil, gas and coal reserves. Today, however, the bioeconomy is no longer driven by rising price expectations for fossil resources. Instead, science and technology and innovation for sustainability have moved to the forefront, because of the perceived need to deal with the present and future threats of the features of the Anthropocene for people and planet. Life science innovations are at the center of these innovations, accompanied by social innovations. The bioeconomy agenda has broadened toward including the demand side, i.e., recognizing that without a significant change in economic behavior, climate change and global ecosystems risks cannot be managed. Bioeconomy is now defined as " $\ldots$ the knowledge-based production and use of biological resources to provide products, processes and services in all economic sectors within the frame of a sustainable economic system". ${ }^{1}$ The concept of the bioeconomy is embedded in a circular economy and seeks synergies with other innovations, especially renewable energy, and aims for increased "biologization" of the economy with entirely new products and solutions. ${ }^{2}$ However, bioeconomy is not inherently sustainable. Multiple goal conflicts make it necessary to always consider positive and negative effects at the same time.

\section{Bioeconomy and Sustainability}

A sustainable bioeconomy protects and makes use of nature, while at the same time supporting global food security, climate protection and the regeneration of natural resources, in particular fertile soils, clean air and clean water. The bioeconomy's key role in protecting and restoring nature has been underscored also by the IPBES-report on 'Nature's Dangerous Decline 'Unprecedented;' Species Extinction Rates 'Accelerating". ${ }^{3}$ Another recent example of the relation between bioeconomy and sustainability is the IPCC Report on Climate Change and Land. ${ }^{4}$ The report stresses that all assessed modelled pathways that limit warming to $1.5^{\circ} \mathrm{C}$ or well below $2{ }^{\circ} \mathrm{C}$ require land-based mitigation and land-use change, with most including different combinations of reforestation, afforestation, reduced deforestation, and bioenergy.

Bioeconomy is not a "sector." By encompassing all economic sectors, the bioeconomy can be compared to the information and communication technology because of its penetration of the economy as a whole, driven by two forces: innovations and demand (from industries and consumers). Establishing a sustainable bioeconomy offers the opportunity to decouple economic growth from resource consumption through efficient methods and innovation. This puts the bioeconomy at the center of new industrial strategies. Aspects of energy efficiency, sustainable lifestyles, circularity and waste prevention determine the discussion on a sustainable bioeconomy in the $21^{\text {st }}$ century.

We can expect that technological progress, particularly in the life sciences, will lead to the development of biobased products that combine sustainability with increased consumer benefit and thus enable new concepts of lifestyle. In Silicon Valley, for example, the foundations of a "post-animal bioeconomy" is laid by using the newest technology with the aim of a more resource-efficient and sustainable food production. Start-ups in Germany have successfully developed nutrient-rich, non-animal products from algae, insects, and plant proteins. Large consumer goods companies are including biobased product innovations in their portfolio, such as biobased packaging, vegan food, biobased cosmetics or children's toys. Today, most consumers practice a mix of sustainable and unsustainable behaviors. Two reasons for that are that they still do not really see that they can make a difference as individuals and that higher consumer prices for more sustainable products are seen as a hurdle. For example, $31 \%$ of German consumers acknowledge the purchasing of biobased products as very important, but only $10 \%$ are doing this already. Increased awareness creation and communication measures as well as education and dialogue strategies will play a key role. ${ }^{5}$

\section{The Set of Innovations for Sustainable Bioeconomy TECHNOLOGICAL INNOVATION}

Life sciences are driving bioeconomy from a sciences side. Breakthroughs in research will enable new biotechnological applications and bio-innovations in the future. Immunotherapies, enzymes for medicine and the industrial bioeconomy are already based on this. Biobased products can have special properties and functions, such as, they can reproduce independently, form active ingredients to ward off harmful substances, repair themselves,

(C) Joachim von Braun 2020; Published by Mary Ann Liebert, Inc. This Open Access article is distributed under the terms of the Creative Commons License (http://creativecommons.org/licenses/by/4.0), which permits unrestricted use, distribution, and reproduction in any medium, provided the original work is properly cited. 


\section{KNOWLEDGE-BASED BIOECONOMY}

parts can be regrown and adapt independently to environmental changes and they fit into natural cycles. Most processes run efficiently at room temperature and under low pressure. If we use principles of nature and biology intelligently, we can develop better products and processes. Specific examples for such biobased product innovations are biotech spider silk, bioplastics, new packaging, biobased materials in automotive manufacturing, functional textiles, recyclable clothes or mushroom furniture. Examples for biobased processes and technologies are biobased $3 \mathrm{D}$ printing, bionics and robotics, large-scale technical use of $\mathrm{CO}_{2}$ or biomanufacturing with cell-free systems. Furthermore, these new products and processes are embedded in new industrial and urban concepts: Biocities, for example, with algae houses, wood buildings, insect farms, urban and indoor farming and more.

\section{SOCIAL INNOVATION}

Some social innovations that can already be attributed to the bioeconomy are urban gardening, food-sharing platforms, local energy grid communities, eco-villages and solidarity-based agriculture for city dwellers. However, the change to a biobased and resource-light society also requires a dialogue between politics, civil society, economy, science and citizens. The media and education institutions also play a prominent role here, to be part of an honest discussion of opportunities and risks, and the creation of socially robust knowledge. In this area, various forms of participation and dialogue are currently being increasingly carried out in the fields of new biotechnologies, among others. The implementation of these formats requires the involvement of relevant actors. These include consumer groups and social initiatives, representatives from industry and biobased companies, and political decision-makers who remove regulatory hurdles for innovation and transformation processes, but also ensure sustainability. In this context, new forms of participation, such as "citizen science", will also gain in importance. ${ }^{6}$

\section{ORGANIZATIONAL \& POLITICAL INNOVATION}

By adapting governance structures, it may be possible to minimize the goal conflicts described above. This requires increased international and intergovernmental cooperation in order to harmonize the legal framework conditions for the bioeconomy. The need for international cooperation arises particularly with regard to measuring resource footprints and monitoring the impacts of an expanding bioeconomy. The establishment of international platforms to ensure a continuous and open dialogue between scientists, policy makers, companies and citizens could, for example, provide support. ${ }^{7}$ Effective bioeconomy monitoring and measuring systems should be installed to ensure that technological and economic progress are benefiting societal development and goals of sustainability. ${ }^{8}$

\section{The Way Forward}

Further development of the bioeconomy will be a joint task of politics, industry, citizens and research. Governments will be responsible for providing a strategic policy framework and incentives for bioeconomy development. In this regard, they will need to promote a supportive innovation ecosystem and business environment, while ensuring long-term societal dialogue. Industry and business will be responsible for investing in promising innovations and emerging businesses in the bioeconomy. Citizens will determine future consumption patterns by developing environmentally and climate-friendly behavior, and science communities need to be transparent with their inventions and open to discussions to maintain and strengthen trust in science. ${ }^{9}$ The German Bioeconomy Council initiated the first Global Bioeconomy Summit in 2015 and in 2018 again, around 700 highranking representatives from politics, science, civil society and the business sector and from more than 70 countries met in Berlin for the $2^{\text {nd }}$ Global Bioeconomy Summit. On $19^{\text {th }}$ and $20^{\text {th }}$ November, 2020 the global bioeconomy community will meet for a third time in Berlin for the Global Bioeconomy Summit 2020 to discuss recent trends in bioeconomy policy activities and emerging opportunities of global and local relevance. ${ }^{10}$ The GBS2020 will again provide thought leadership in shaping global bioeconomy policy and contribute to sustainable development.

Dr. Joachim von Braun is Professor for Economic and Technological Change, Bonn University Director, Center for Development Research (ZEF), Germany, and President of the Pontifical Academy of Sciences. Genscherallee 353113 Bonn, Germany. Phone: +49 228 731800. Web: www.zef.de. E-mail: jvonbraun@uni-bonn.de.

\section{REFERENCES}

1. German Bioeconomy Council (2013): Bioökonomie-Politik-Empfehlungen für die 18. Legislaturperiode. Available at: http://biooekonomierat.de/fileadmin/ Publikationen/empfehlungen/Politikempfehlungen.pdf (Last accessed April 2016).

2. von Braun J. Bioeconomy-Science and Technology Policy to Harmonize Biologization of Economies with Food Security. In: Sahn D, ed. The Fight Against Hunger and Malnutrition. Oxford University Press, 2015, pp 240-262

3. IPBES. Media Release. Nature's Dangerous Decline 'Unprecedented' Species Extinction Rates 'Accelerating' (2019). Available at: https://ipbes.net/news/ Media-Release-Global-Assessment (Last accessed February 2020).

4. IPCC. Climate Change and Land (2019). Available at: https://ipcc.ch/site/assets/ uploads/2019/08/4.-SPM_Approved_Microsite_FINAL.pdf (Last accessed February 2020).

5. Hempel C, Will S, Zander K. Bioökonomie aus Sicht der Bevölkerung. Braunschweig: Johann Heinrich von Thünen-Institut, Thünen Working Paper 115, 2019. DOI:10.3220/WP1545134625000.

6. von Braun J. Bioökonomie - auf dem Weg zu nachhaltigem Wirtschaften. In Binswanger HC, Ekardt F, Grothe A, et al. (Eds) (2017). Jahrbuch Nachhaltige Ökonomie 2016/2017. Im Brennpunkt: Ressourcenwende. Metropolis: Marburg.

7. International Advisory Committee (IAC) of the Global Bioeconomy Summit (2015): Communiqué of Global Bioeconomy Summit - Making bioeconomy work for sustainable development. Available at: http://gbs2015.com/fileadmin/ gbs2015/Downloads/Communique_final.pdf (Last accessed April 2016).

8. Wesseler J, von Braun J. Measuring the Bioeconomy: Economics and Policies Annual Review of Resource Economics. Vol. 9:275-298 (October 2017). https:// doi.org/10.1146/annurev-resource-100516-053701

9. Pontifical Academy of Sciences. Transformative roles of science in society: From emerging basic science toward solutions for people's wellbeing. Final Statement of the 2018 PAS Plenary Session. Vatican (2018). Available at: www.pas.va/ content/accademia/en/events/2018/plenary2018/final_statement.html (Last accessed May 2020)

10. Global Bioeconomy Summit. Available at: https://gbs2020.net/ (Last accessed May 2020). 